\title{
AN INTERACTION OF ARCHITECTURAL DESIGN AND PERCEIVED VALUE TOWARD REVISIT INTENTION IN ARTIFICIALLY BUILT ATTRACTIONS
}

\author{
Niti Rattanaprichavej \\ Thammasat University, Thailand \\ e-mail:nitir2001@yahoo.com
}

\begin{abstract}
Considering the significant growth of artificially built attractions in Thailand, the objective of this research is to study architectural design and perceived value toward revisit intention in artificially built attractions. The designs of these attractions are derived from foreign countries that would not be suitable for the Thai environment. Nevertheless, this could be considered through the perspective of marketing growth, which depicts artificially built attractions receiving good response from visitors. Therefore, it was essential to analyze customers' attitude toward their travel and revisit intention to artificially built attractions. The research uses the quantitative method with 342 participants who visited the artificially built attractions. The result indicates that emotional, functional, and social values influence the revisit intention. Furthermore, the architectural design had a positive influence on emotional and social values. Though architectural design had no direct influence on revisit intention, it had indirect influence via emotional and social values. By analyzing the independent and dependent variables, it was indicated that, although all independent variables affect dependent variables, the scores of each of these factors were not high. Therefore, it can be concluded that artificially built attractions still have space for improvement in terms of perceived value in order to foster revisit intention.
\end{abstract}

Key words: artificially built attractions, perceived value, revisit intention.

JEL Classification: R30.

Citation: Rattanaprichavej N., 2019, An Interaction of Architectural Design and Perceived Value Toward Revisit Intention in Artificially Built Attractions, Real Estate Management and Valuation, vol. 27, no. 3, pp. 69-80.

DOI: $10.2478 /$ remav-2019-0026

\section{Introduction}

At present, many real estate properties have been developed with particular themes in order to differentiate them from common real estate. The idea of analogies had been applied to simulate different locations from other countries or areas. These include commercial buildings in China, shopping malls in Italy, Japan, England, France, the United States, and Switzerland, and residential buildings in Indonesia, Cambodia, Egypt, Singapore, and the United Arab Emirates (BOSKER 2013). With innovations in design, construction, and management, it is noteworthy that they considerably encourage visitors to visit artificially built attractions. However, another important focus of the investment and development of real estate structures is the long economic life (JACOBUS 2012; WURTZEBACH, MiLES 1994). Therefore, the number of visitors who only visit the artificially built attractions only a single time during the opening stage does not indicate the consistent revenue which is needed for developers to break even in approximately 10 to 20 years. Repeat visitors are essential to any kind of income producing property. A higher cost of special development, decoration, materials, 


\section{S sciendo}

construction, and design, along with the issue of maintenance, leads to greater complications of investing in artificially built attractions than usual. In general, the design in one country would not be ideally applicable in other places in terms of the appropriation of the contexts and can be misused regarding other perspectives (POTTS, ANKRAH 2013). Additionally, it should be designed coherently to a certain area (PROJECT FOR PUBLIC SPACES (PPS) 2017). Therefore, it is interesting to study the effects of real estate investment on artificially built attractions and whether it can lead visitors to perceive the intended value. This is because there is merely a trend of interest in different architecture and design. Consequently, if it is not capable of attracting visitors' revisit intention in the long run, it finally results in the project lacking consistent revenue and sustainability.

Moreover, online shopping is a growing trend of buying things, such as clothes, food, accessories, decorations, and other items on the internet (MOTWANI 2016). Therefore, shopping center developers emphasize the concept of placemaking in order to create a unique space which is more meaningful than ordinary areas and can be called a "place" (NORMOYLE 2016). Customers who visit the place must have exceptional experiences enhancing their emotional and social values more than a common shopping center which only sells things via online platforms, without any added value addition. It is thus a way to maintain the competitive advantages of physical shops. This idea about place is interesting evidence supporting the idea of artificially built attractions.

As mentioned earlier, the main objective of this research is to study how particular factors affect revisit intention in artificially built attractions. The suggestions from the research results will help developers have sufficient information in order to make decisions regarding whether to invest or not to invest in artificially built attractions in terms of suitability and sustainability. No research had been conducted on artificially built attractions and thus the present research yields unique knowledge on artificially built attractions.

\section{Literature reviews}

The review of literature is based on the concept of perception theory, which regards the process of obtaining and interpreting the data around us through the use of our senses. The perception of a person involves some psychological factors, including learning, experience, motivation, emotion, etc. (Henry, Peters 2010). Perception theory has been studied in many dimensions, such as risk perception, self-perception, visual perception, and social perception; that related to artificially built attractions will be a study of the perception of tourist destinations and place perception. It concerns the perception of various elements of a place (REITSAMER, BRUNNER-SPERDIN 2017). Therefore, in this study, perception theory is an important basis for studying three constructs, i.e.: architectural design, perceived value and revisit intention. It is the study of three issues, i.e.: 1) the perception of special architectural design patterns in artificially built attractions 2) value perception, in the form of evaluating value of the studied attractions in various dimensions, and 3) perceiving value in such attractions should lead visitors to revisit or not revisit the studied attractions.

\subsection{Revisit intention}

Revisit intention is the state of planning to visit an attraction again in a particular period (WOODSIDE, KING 2001). Revisits are parrticlarily important, as they show the appeal of attractions along with the effectiveness of the investor's cost management. Re-consumption is a marketing aspect discussed in tourism-related literature which is used to attract revisting customers, which is more cost effective than acquiring new customers (OPPERMANN 1998). It also represents the perception of and satisfaction with the previous visit, which is related to social trends and affordability (WEAVER, LAWTON 2002).

The revisit intention of an individual comes from recognition, which comes from the happiness and pleasure associated with a previous visit to attractions. It leads to pleasure and a willingness to revisit the same places in the future (UM et al. 2006), and consequently occurs in the forms of suggestion, invitation, and word-of-mouth used to persuade others to revisit the places (EUGENIO MARTIN, AVILA-FOUCAT 2008; LAU, MCKERCHER 2004; LEE et al. 2009). In addition, perceived value is a significant indicator of the repurchase of products and services (FANDOS et al. 2006; MENCARELLI, Lombart 2017; OH, 1999; PARASuraman, Grewal 2000; Petrick, BACKMAN 2002; Pham et al. 2016; SWEENEY, SOUTAR 2001). Previous research indicated that the perceived value indirectly influences the revisit intention and loyalty of visitors (CRONIN et al. 2000; LEE et al. 2011; LIU, ZHOU 2009).

From the relevant literature, it can be concluded that the factor affecting revisit intention, as most scholars believe, is perceived value, which considerably influences the decision to revisit. 
Consequently, this research focuses on and emphasizes different aspects of perceived value of people visiting artificially built attractions. The revisit intention measurement is adapted from a study by STYLOS et al. (2016).

\subsection{Perceived Value}

Perceived value can be described as the overall evaluation of the benefit acquired by an individual based on recognition (CHIU et al. 2012). Customer Perceived Value (CPV) is the customers' opinion of particular market branding, products and services based on how well they are able to influence their satisfaction and the increasing or decreasing value provided by different kinds of products and services with respect to cost (BEST 2005; CERASALE, STONE 2004; LOVELOCK, WIRTZ 2011; ZEITHAML et al. 2009). Customers have different perspectives of the perceived value of different kinds of products and services. However, the same products and services would lead to different perceived values of customers' perspectives as well. This difference can apply to the evaluation of the perceived value of visiting attractions due to the fact that each attraction has different characteristics of products and services included in various facilities and places (OZTURK, QU 2008). Thus, visitors' perceived value can be evaluated in various perspectives, such as in terms of monetary value or non-monetary value. The monetary value is what travelers are willing to pay in order to get the service, experience and facilities they desire when travelling (ZeITHAML et al. 2009). It can be the actual expenditure on the trip or a comparable price from past experience. Non-monetary values may include time spent on searching for information, evaluation of the attraction's brand and image, ease of accessibility, and quality of travel activities (OZTURK, QU 2008).

According to literature review, perceived value is the influential factor for revisit intention and has multi-dimensional aspects which reflect different perceived values, such as perceived social value, perceived emotional value, and perceived functional or utility value. These variables can be explained thoroughly as particular components of perceived value, as adopted from SANCHEZ et al. (2006), KIM et al. (2011), SWEENY et al. (1999), and FANDOS, et al. (2006).

\section{1) Functional value}

Functional value concerns the efficiency of the work process and utility of products, and particularly emphasizes physical features and usage (SHETH et al. 1991), such as, durability, reliability, and price (KIM et al. 2011). Some theories describe it as the benefits available to serve to customers (STRAHILEVITZ, MYERS 1998). Functional value can be regarded as influential to a consumer's decision with respect to the economic utility theory (SHETH et al. 1991). However, perceived functional value associated with context differs from usual functional value (FANDOS et al. 2006; SWEENY et al. 1996) with regard to different details. EL-ADLY and EID (2015) developed a tool to indicate the value of the shopping mall "MALLVAL" by basing perceived value only on functional value associated with the context of the shopping mall in order to extract the differences between the general products.

It can be seen from the review of literature that functional value is significant because it is a part of the measurement of the overall perceived value of artificially built attractions, and is one of the predictors of revisit intention; once visitors assess the functional value of a given attraction in a positive light, it leads them to revisit it.

\section{2) Emotional value}

Emotional value comprises the different emotions influencing a customer's decision-making. Emotional value leads customers to a positive or negative emotion, and associating a product with that given emotion (KIM, GUPTA, KOH 2011). It involves experiencing beauty and fun, both of which affect the customers' emotions positively. In terms of emotion, happiness and a feeling of welcome are necessary in order to attain customer satisfaction (PETRICK 2002). According to ROBINETTE et al. (2000), the decision of customers to stay in a particular hotel may be associated with the emotional value of the first impression, which induces brand loyalty, which in turn leads to word-of-mouth and revisits. Additionally, a study by PETRICK (2002) regarding perceived value and service satisfaction identifies the construct indicators as being: utility or function, emotion, and social. The study also indicated that customers recognize all aspects of perceived value, with the most important being emotional value. This value cannot be easily imitated, as it is unique to each individual. Therefore, emotional value is one of the key factors to the success of any business. Thisalso relates to studies by CROMPTON and MCKAY (1997) and LEE and CHOI (2010), who focused on the in-depth feelings or emotions of humans 


\section{S sciendo}

and discovered that, compared to other factors, emotional value is a powerful indicator affecting satisfaction and decision-making regarding the purchase of products and services. Similarly, EID and EL-GOHARY (2015) asserted that emotional value has more influence on satisfaction and behavior tendencies than functional value.

It can be concluded from the above literature review that emotional value directly affects revisit, and is a component that developers should focus on, working to invoke positive emotions in customer and influence their preferences. This will support a business's sustainability as well as the revisit intention for artificially built attractions.

\section{3) Social value}

Social value refers to the social norms which most people accept as good morals or practices that, in certain circumstances, lead to behaviors that create bonding, understanding, and acceptance of the social status of an individual (KIM et al. 2011; ZEITHAML 1998). It also relates to products and service utilities, in term of whether they would result in a positive experience which people in the society would define as good in a particular context in terms of goods, values, utility, rightness, and appropriation. Most people consider these to be a priority or a way of behaving. Therefore, an individual or public group can play a significant role in directly influencing customers' decisionmaking (BURNKRANT, COUSINEAU 1975). Marketers therefore also implement this action in order to raise awareness of the products and services and establish their reputation for raising upsell values (SHANKA, PHAU 2008). Social value plays an important role regarding travelers' perceptions, which is actually the perceptions of their experience (MORGAN et al. 2010; Williams, SOUTAR 2000). When experience is shared with society, it can impress others leading to acceptance and, consequently, improving the individual's image (SWEENEY, SOUTAR 2001; PREBENSON, XIE 2017). Nevertheless, social values or norms can be changeable depending on the time period (SWEENEY, SOUTAR 2011). Some researchers have defined social value through various perspectives and associated the result with revisit intention (NOYPAYAK 2009). Social value is considerably important in enhancing attractiveness because it is an effective marketing tool which can boost visitors' satisfaction and revisit intentions, especially in today's technological advancement of social networks.

\subsection{Architectural design}

Design refers not only to the physical creation or improved aesthetics, but can also have an influence on people's emotions and behavior, as defined by the concept of environmental psychology. It is the relationship between environment and design and their influence on users' expectations in terms of behavioral, emotional, or reaction perspectives (BELL et al. 2001; DONOVAN, ROSSITER 1982; GIFFORD 2007; KOPEC 2012). The ways to measure the success of architectural design in terms of monetary benefits are somewhat limited; nonetheless, studies on the influence of design on project success have found connections with several aspects, such as attitude towards the destination, destination attachment (KUMAR, KIM 2014; REITSAMER et al. 2016), value added (BABIN, ATTAWAY 2000), recognition (BAKER et al. 2002; EL-ADLY, EID 2015) behavior (BITNER 1992; MICHON et al. 2015), property value (PAWLICKA 2014), loyalty (BAKER et al. 2002; VIGOLO 2014), and occupancy rate (WAKEFIELD, BAKER 1998).

According to BitNer (1992), BITNER and BARNES (1992) and TURLEY and MillimAn (2000), a mall environment consists of mall recreation, mall interior and mall staff, which were all found to influence the perceived value, satisfaction, and loyalty (EL-ADLY, EID 2015). The mall environment should excite customers, increasing their desire to stay and eventually revisit (BAKER, WAKEFIELD 1998). The layout of the mall and attractive shop tenants are the most influential factors affecting customer loyalty. Design is an indicator which customers, especially those who have not been at the shop before, use to evaluate the products in the shops, (BAKER et al. 2002). Similarly, the design of the environment in a restaurant significantly relates to price expectations regarding food (VERHOEVAN et al. 2009). However, BAKER et al. (1994) stated that the design does not affect shop image while atmospheric and social factors do. Thus, it might be concluded in this research that design might not be able to directly promote a group's perceived value. Moreover, KUMAR and KIM (2014) emphasize the idea of a store as a brand, according to which design does not influence the customers' response. Similarly, the study of mall renovation indicated that it does not directly affect purchasing behavior, which depends more on mediators such as the arrangement of the mall environment (CHEBAT et al. 2014). 
Furthermore, the study of place brand indicated that the components of a place, such as quality, image and confidence, relate to the social prestige and the social identity of those who visit (JACOBSEN 2012). Also, from the study of the value of a workplace, it can be concluded that the workplace has a potential influence on social values in terms of image, satisfaction, reliability, and reputation as perceived by customers (CHARTERED ASSOCIATION OF BUILDING ENGINEERS (CABE) 2005; PETRULAITIENE, JYLHA 2015). In brief, it can be inferred that design is a significant factor influencing perceived emotional or social values, and directly and indirectly influences revisit intention (Figure 1).

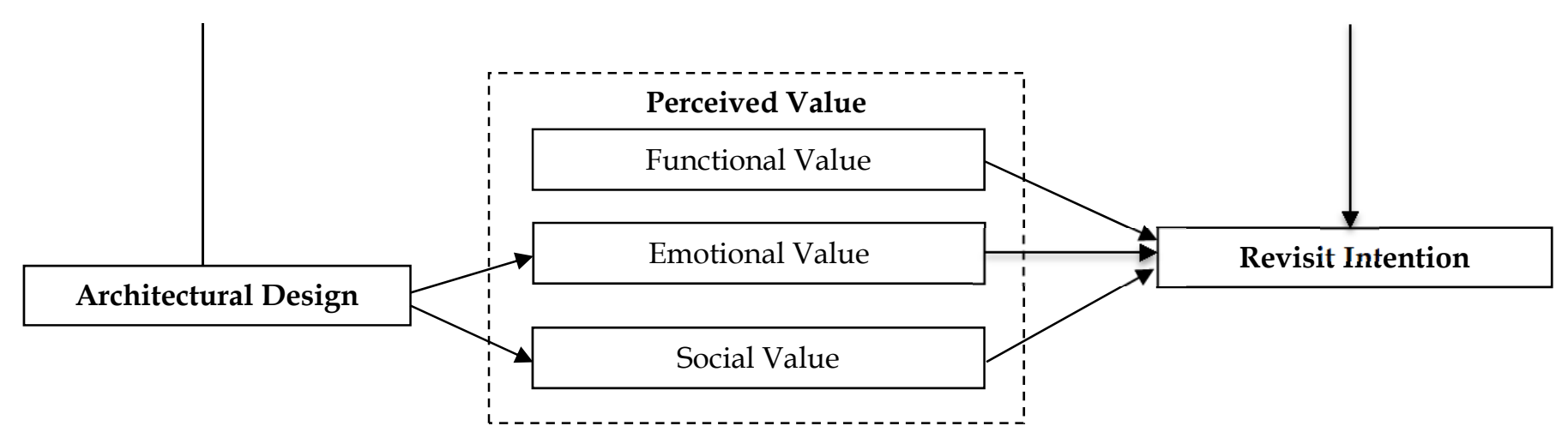

Fig. 1. Conceptual Framework. Source: own study.

\section{Research methodology}

The present research was conducted with a quantitative approach using a questionnaire developed based on a literature review, which was distributed online and offline through judgmental sampling. The data was collected from those who visited artificially built attractions, such as: J Park Sriracha, Veneto Suanphueng, Pickadaily Onnut, London Street Pattanakarn, Terminal 21 Asoke, Mimosa Pattaya, and The Venezia Huahin in the past year (2018) in Thailand (Table 1).

Table 1

Details of Artificially Built Attractions

Artificially Built Attractions
$\begin{gathered}\text { Terminal 21 Shopping Mall } \\ \text { A multi-country-themed shopping \& dining complex in } \\ \text { Bangkok city, including design styles from Rome, the } \\ \text { Caribbean, Tokyo, Istanbul, Paris, London, } \\ \text { San Francisco and Hollywood. } \\ \text { (opened in 2012) }\end{gathered}$
$\begin{gathered}\text { An Italian-themed shopping \& dining complex. } \\ \text { (opened in 2010) }\end{gathered}$




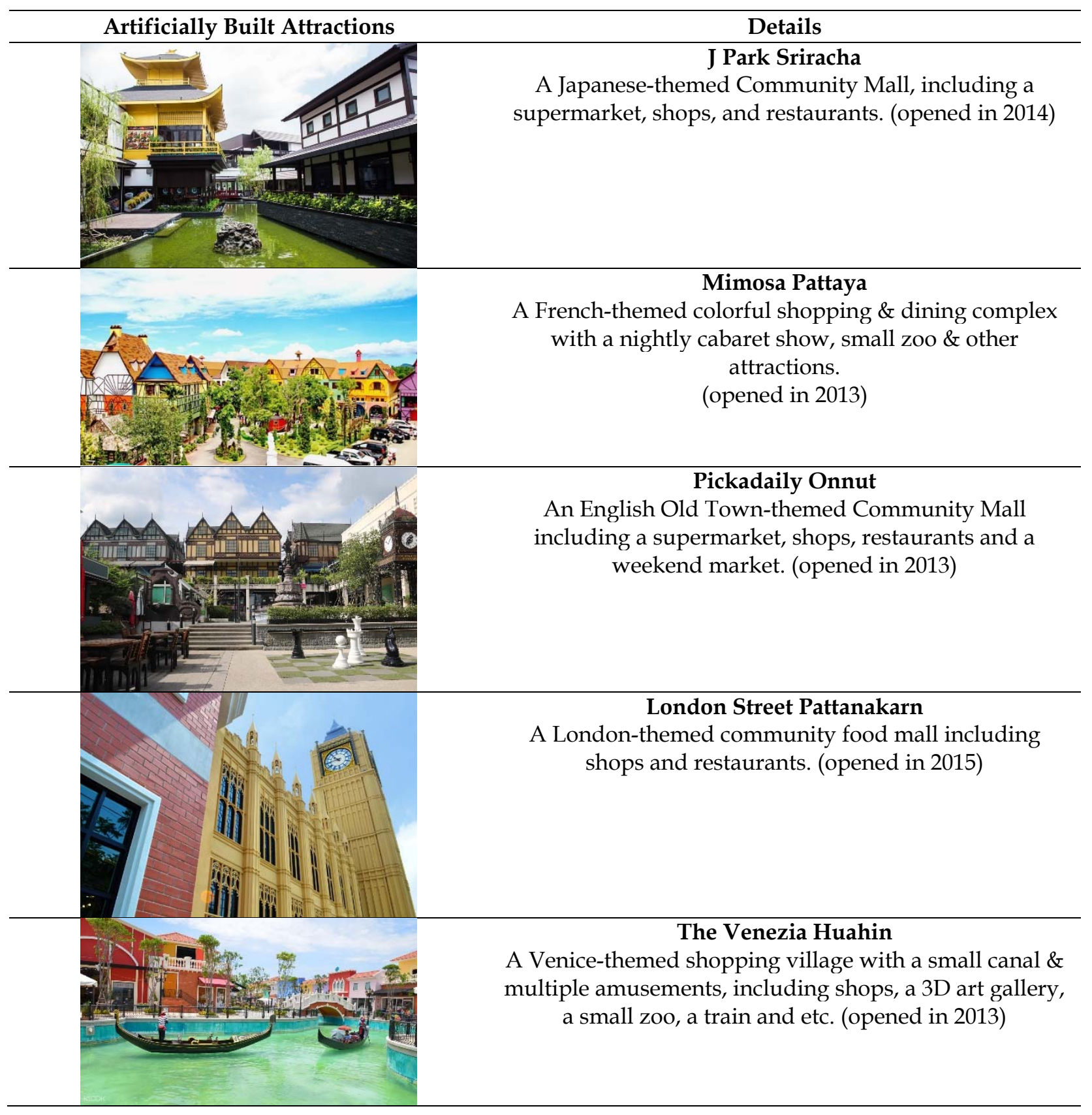

Source: own study.

A five-point likert scale questionnaire was adopted from the literature review. A pretest with 15 samples was conducted in order to ensure the quality of the questionnaire, and it was tested through reliability analysis by the internal consistency technique which demonstrated that each factor had a Cronbach's alpha value of more than 0.70. For a structure validity test, Exploratory Factor Analysis (EFA) via factor analysis with principal axis and direct oblimin rotation was conducted, and all factors were adjusted to gain the highest validity.

Partial Least Square Structural Equation Modeling (PLS-SEM) was utilized in this research in order to study the relationship between revisit intention, perceived value, and architectural design, using the bootstrapping technique to test the statistical significance. The path coefficient at the significance level of 0.05 was $p<0.05$, and the $t$-value was more than 1.96 , which shows that the coefficient supports the hypothesis of the research.

\section{Research result}

In this section, research results generated by collecting online and offline samples, descriptive data, and the relationship of variables are discussed. 


\subsection{Sample}

Questionnaires were distributed and 444 responses were obtained. However, only 342 responses were valid, with a 77.02 percent return rate. It was observed that Terminal 21 was the most familiar artificially built attraction for 162 people constituting 47.4 percent of responses. Palio Khao Yai was the second, chosen by 51 people, i.e. 14.9 percent. The rest of the selected artificially built attractions varied, constituting approximately 40 percent in total.

Most respondents were female (59.5 percent) and more than half were 20 to 40 years of age, indicating the main visitors of the sites. The educational level of the respondents was at least a bachelor's degree (99.7 percent), and 37.1 percent were in officer level; 14.9 percent were supervisors, and approximately 50 percent were managers or entrepreneurs. As observed in the samples, the position in the workplace relates to the age range. The majority ( 40.9 percent) travel to artificially built attractions with friends, whereasb27.5 percent, 23.7 percent, and 7.3 percent travel with family, couples, and alone, respectively. Approximately two hours were spent by visitors at the artificially built attractions.

The main purpose of visiting artificially built attractions, making for 80 percent of the responses, was to be impressed by the attractions and eat out at restaurants, with only 8.5 percent of the respondents visiting such places for shopping purposes, which, according to the data, is totally different from the purpose of visiting ordinary shopping malls. The most powerful public relation of artificially built attractions was social media, and the second was word-of-mouth, which leads us to believe that these kinds of attractions might need different communication channels compared to other common attractions.

\subsection{Comparison of average scores of architectural design, perceived value and revisit intention}

Table 2

Average Scores of Architectural Design, Perceived Value and Revisit Intention (n=342)

\begin{tabular}{ccccc}
\hline Variables & Minimum & Maximum & Mean & SD \\
\hline Architectural Design & 1.20 & 5.00 & 3.76 & .67 \\
\hline Functional Value & 1.00 & 5.00 & 3.37 & .76 \\
\hline Emotional Value & 1.00 & 5.00 & 3.56 & .70 \\
\hline Social Value & 1.00 & 5.00 & 2.94 & .79 \\
\hline Revisit Intention & 1.00 & 5.00 & 3.26 & .80 \\
\hline
\end{tabular}

Source: own study.

From Table 2, it can be depicted that the samples had a mean of each factor of no more than 4.00, which shows that visitors did not perceive the value of visiting artificially built attractions highly. The social value score was at the lowest level, i.e. 2.94, reflecting that visitors did not really acknowledge their social value. Furthermore, the revisit intention score was at a low level of only 3.26, which reflects that they also had low intentions of revisiting the attractions. This is a crucial point that might affect revenue for developers in the long run.

\subsection{The Relationship among Architectural Design, Perceived Value, and Revisit Intention}

According to Table 3 and Figure 2, emotional value had a positive influence on revisit intention, having the highest coefficient of 0.43 , and a significance level of p-value at 0.00 and $t$-value at 6.21 . Furthermore, functional value had a positive influence on revisit intention with a coefficient of 0.31 and a significance level of $p$-value at 0.00 and $t$-value at 4.90, whereas social value had a positive influence on revisit intention with a coefficient of 0.31 and a significance level of p-value at 0.02 and $\mathrm{t}$-value at 2.21. Architectural design had a positive influence on perceived emotional and perceived social value, having the coefficient at 0.71 and 0.35 , respectively at the significance level of p-value at 0.00 and $t$-value at 17.12 and 5.98, respectively. It can be seen that architectural design did not have a significant influence on revisit intention ( $\mathrm{p}$-value $=0.20 \mathrm{t}$-value $=1.27$ ), which was not different from the literature review. Nevertheless, although architectural design did not directly influence the revisit intention as shown in Table 4, it indirectly influenced emotional and social values.

The overall analysis of the model divides the influence on independent variables into direct effect (DE), indirect effect (IE), and total effect (TE). As Table 3 indicates, architectural design influenced 
revisit intention at 0.35 , with the direct effect value at only 0.02 , which is not significant, while indirect effect through emotional and social values at 0.33 . Therefore, it can certainly be concluded that emotional and social values behave as mediators which the architectural design had an influence on, with values of 0.71 and 0.35 , respectively. Functional, social, and emotional values had an influence on revisit intention with values of $0.31,0.43$, and 0.10 respectively.

Table 3

The relationship between architectural design, perceived value, and revisit intention

\begin{tabular}{|c|c|c|c|c|}
\hline & Effects & $\begin{array}{c}\text { Path } \\
\text { Coefficient }\end{array}$ & $\mathrm{t}$-values & p-values \\
\hline Functional value & $\longrightarrow$ Revisit intention & 0.31 & 4.90 & 0.00 \\
\hline Emotional value & $\longrightarrow$ Revisit intention & 0.43 & 6.21 & 0.00 \\
\hline Social value & $\longrightarrow$ Revisit intention & 0.10 & 2.21 & 0.02 \\
\hline \multirow[t]{3}{*}{ Architectural design } & $\longrightarrow$ Emotional value & 0.71 & 17.12 & 0.00 \\
\hline & $\longrightarrow$ Social value & 0.35 & 5.98 & 0.00 \\
\hline & $\longrightarrow$ Revisit intention & 0.02 & 1.27 & 0.20 \\
\hline
\end{tabular}

Source: own study.

Direct and indirect effects

\begin{tabular}{lcccccc}
\hline \multirow{2}{*}{$\begin{array}{c}\text { Dependent } \\
\text { variable }\end{array}$} & $\begin{array}{c}\text { Adjusted } \\
\mathbf{R}^{2}\end{array}$ & Effects & $\begin{array}{l}\text { Architect } \\
\text { ural } \\
\text { design }\end{array}$ & $\begin{array}{c}\text { Functional } \\
\text { value }\end{array}$ & $\begin{array}{c}\text { Emotional } \\
\text { value }\end{array}$ & Social value \\
\hline Revisit intention & 0.53 & DE & 0.02 & 0.31 & 0.43 & 0.10 \\
& & IE & 0.33 & - & - & - \\
\hline Emotional value & 0.50 & DE & 0.35 & 0.31 & 0.43 & 0.10 \\
\hline Social value & & IE & - & - & - & - \\
& 0.12 & TE & 0.71 & - & - & - \\
& & DE & 0.35 & - & - & - \\
& & IE & - & - & - & - \\
\hline
\end{tabular}

Source: own study.

In order to evaluate the structural validity of this research, coefficient determinants of three variables, revisit intention, social value, and emotional value, were studied. The adjusted $R^{2}$ coefficient of revisit intention was at 0.53 , which was influenced by functional, emotional, and social values, and these factors therefore mutually explained the variances of revisit intention at 53 percent. On the other hand, emotional and social values had adjusted $R^{2}$ coefficients of 0.50 and 0.12 respectively, which counted as medium and low, respectively. The two factors were influenced by architectural design, which could explain the variances constituting the percentages of 50 and 12, respectively.

From the above statistical data, it can be interpreted that higher social and emotional values result from architectural design, architectural style, decoration, and attractive coloring. Therefore, architectural design would provide emotional and social values to visitors, and it can be concluded that, although at low compliance with Thailand's environment, visitors' experience of different architectural designs can influence their perceived value and revisit intention. Another viewpoint is that architectural design does not directly influence revisit intention but indirectly influences it through perceived value, as it is apparent that architectural design and perceived value in artificially built attractions are factors that need to be managed in order to generate revisit intention. 
Perceived value is an essential factor for developers, which needs to be emphasized in order to create revisit intention, especially in income generating real estate sectors which require long periods to break even. Developers should focus on emotional value as all re-visitors of artificially built attractions expect emotional experiences that bring about feelings of pleasure, happiness, comfort, and relaxation. Furthermore, considering functional value, comfort and safety of use, circulation, attractive activities, and a diverse mix of tenants are crucial issues. Although social value has the lowest significance among others values, it can be managed with less cost, such as through online sales activities or social media with the aim of building a social group and fostering loyalty.

Interestingly, there is a contradiction at present regarding social media, which is popular for sharing pictures and videos of artificially built attractions visit through various social applications, and was at first expected to have a high level of social influence on revisit intention; research however shows that re-visitors do not focus as much on social value as expectations. In addition, it can be possible that social value affects first-time visitors, especially those who might be associated with the desire to hold the same place in society as their acquaintances. Therefore, it can be pointed out that emphasizing visit and revisit intentions toward artificially built attractions must be considerably varied with respect to details.

\section{Discussion}

Artificially built attractions are attractions that have different characteristics from normal attractions, and had never before been studied in the aspect of revisit intention. Revisit intention, in turn, is an important factor for investment. Therefore, it can be seen that the conceptual framework of this research reflects an attempt to explain the relationship between architectural design, perceived value and revisit intention in a context that is different from previous research. The results of the study have shown the relationship of all three factors, which is in line with the studies of ALLAMEH et al. 2014 and PHAM et al. 2016. In addition, it can be said that emotional value had the highest influence on revisit intention in comparison with functional value and social value, which contrasts with the study of Santini et al. 2018. Although most research shows that perceived value has an influence on revisit intention (FANDOS et al. 2006; MENCARELl, LOMBART 2017; OH, 1999; PARASURAMAN, GREWAL 2000; PETRICK, BACKMAN 2002; PHAM et al. 2016; SWEENEY, SOUTAR 2001), there is some research that does not show the relationship between perceived value and revisit intention (CHANG et al., 2014; CHENG, TSAI 2007). In conclusion, the relationship of factors as well as their level of influence may be varied by different contexts.

By analyzing independent and dependent variables, and comparing them with descriptive data on functional, emotional, and social values, including revisit intention, it was indicated that, although all independent variables affect dependent variables, scores of each factor were not high. Therefore, it can be concluded that there is still room left for improvement in the development of artificially built attractions when it comes to fostering revisit intention. Real estate developers who want to develop artificially built attractions can use these research results to help them formulate an appropriate strategy that is in agreement with the customers' expectations.

\section{References}

AllameH S.Y., POOL J.K., JABeRI A., SALEHZADEH R., AsADI H. 2015, Factors influencing sport tourists' revisit intentions: The role and effect of destination image, perceived quality, perceived value and satisfaction, Asia Pacific Journal of Marketing and Logistics, Vol. 27 Issue: 2, pp. 191-207.

Avila-Foucat S., EugENIO-MarTin J. L., 2008, Linking Environmental Quality Changes and Tourism Demand with Repeat Visits Method. Tourism and Sustainable Economic Development: Macroeconomic Models and Empirical Methods, Edward Elgar Publishing Limited.

BAKER D. A., CROMPTON J. L., 2000, Satisfaction and Behavioral Intentions, Annals of Tourism Research, Vol. 27(3), 785-804.

Bell P.A., Greene T.C., Fisher Jeffrey D., BAum A., 2001, Environmental Psychology, New York: Routledge Taylor and Francis Group, LLC.

BOSKER B., 2003, Original Copies: Architectural Mimicry in Contemporary China, Honolulu: University of Hawai'i Press.

BURNKRANT R., COUSINEAU A., 1975, Informational and Normative Social Influence in Buyer Behavior, Journal of Consumer Research, Vol. 2, pp. 206-215. 
Cerasale M., StOne M., 2004, Business Solutions on Demand: Transform the Business to Deliver Real Customer Value, London: Kogan Pages.

CHANG L.L., BACKMAN K.F., HuANG Y.C., 2014, Creative Tourism: A Preliminary Examination of Creative Tourists' Motivation, Experience, Perceived Value and Revisit Intention, International Journal of Culture, Tourism and Hospitality Research, Vol. 8 Issue: 4, pp. 401-419.

CHEN C.F., TSAI D.C., 2007, How Destination Image and Evaluative Factors Affect Behavioral Intentions? Tourism Management, Vol. 28 No. 4, pp. 1115-1122.

CHIU C. M., Hsu M. H., LAI H., CHANG C. M., 2012, Re-examining the Influence of Trust on Online Repeat Purchase Intention: The Moderating Role of Habit and its Antecedents, Decision Support Systems, Vol. 53(4), pp. 835-845.

CROMPtON J. L., MCKAy S. L., 1997, Motives of Visitors Attending Festival Events, Annals of Tourism Research, Vol. 24(2), pp. 425-439.

Cronin J. J., Brady M. K., Hult G. T. M., 2000, Assessing the Effects of Quality, Value, and Customer Satisfaction on Consumer Behavioral Intentions in Service Environments, Journal of Retailing, 76 (2), pp. 193-218.

EID R., EI-GOHARYH., 2015, The Role of Islamic Religiosity on the Relationship between Perceived Value and Tourist Satisfaction, Tourism Management Journal, Vol. 46, pp. 477-488.

Fandos C. J., Garcia S. J., TenA A. M., MonZOnis L. J., 2006, Customer Perceived Value in Banking Services, International Journal of Bank Marketing, Vol. 24(5), pp. 266-283.

GIFFORD R., 2007, Environmental Psychology: Principles and Practice, (4th edition), Colville, WA: Optimal Book.

Henry C., Peters JAMES F., 2010, Perception-based Image Classification, International Journal of Intelligent Computing and Cybernetics, Vol. 3 Issue: 3, pp. 410-430.

HolbrooK B. M., 1994, The Nature of Customer Value: An Axiology of Services in the Consumption Context, in Service Quality: New Directions in Theory and Practice, ed. Roland Rust and Richard L. Oliver, Thousand Oaks: SAGE Publications.

HolbRoOK B. M., 1999, Introduction to Consumer Value in Consumer Value: A Framework for Analysis and Research, ed. M. B. London: Routledge.

KIM H. W., GuPTA S., KOH J., 2011, Investigating the Intention to Purchase Digital Items in Social Networking Communities: A Customer Value Perspective, Information and Management, Vol. 48(6), pp. 228-234.

KIM Y., HAN H., 2010, Intention to Pay Conventional Hotel Prices at a Green Hotel: A Modification of the Theory of Planned Behaviour, Journal of Sustainable Tourism, 18(8), pp. 997-1014.

LAU L. S., MCKERCHER B. ,2004, Exploration versus Acquisition: A Comparison of First-time and Repeat visitors. Journal of Travel Research, Vol. 42(3), pp. 279-285.

LEE J., LEE C., CHOI Y., 2010, Examining the Role of Emotional and Functional Values in Festival Evaluation, Journal of Travel Research.

LEE S., JEON S., KIM D., 2011, The Impact of Tour Quality and Tourist Satisfaction on Post-purchase Behavioral Intention: The Case of Chinese Tourists in Korea, Tourism Management, Vol. 32(5), pp. 11151124.

Li H., 2014, Analysis of formation mechanism of revisit intention: Data from East China, Paper presented at the 2014 International Conference on Global Economy. Commerce and Service Science, (GECSS14), Phuket.

LIU Y., ZHOU X., 2009, Corporate Social Responsibility and Customer Post-Purchase Behavior Intention: A Conceptual Framework, Paper Presented at the Proceedings of the 2009 6th International Conference on Service Systems and Service Management, ICSSSM 09.

Lovelock C., Wirtz J., 2011, Services Marketing: People, Technology, and Strategy, 7th international ed. Upper Saddle River: Pearson Prentice Hall.

Morgan M., Lugosi P., RitchiE J. R. B., 2010, The Tourism and Leisure Experience Consumer and Managerial Perspectives, MPG Books Group Ltd. Great Britain.

OLIVER RichARD L., 1997, Satisfaction: A Behavioral Perspective on the Consumer, New York. NY: McGraw-Hill.

NOYPAYAK W., 2009, Value Dimensions of Thailand as Perceived by U.K. Tourists, RU, International Journal. Vol. 3(1), pp. 141-154.

OPPERMANN M., 1998, Destination Threshold and the Law of Repeat Visition, Journal of Travel Research, Vol. 37(2), pp. 131-137. 
ÖZTÜRK A.B., QU H., 2008, The Impact of Destination Images on Tourists' Perceived Value, Expectations, and Loyalty, Journal of Quality Assurance in Hospitality \& Tourism, Vol. 9(4), pp. 275-297.

PARASURAMAN A., GREWAL D., 2000, The Impact of Technology on the Quality-Value-Loyalty Chain: A Research Agenda, Journal of the Academy of Marketing Science, p. 28.

Petrick J. F., BACKMAN S. J., 2002, An Examination of the Construct of Perceived Value for the Prediction of Golf Travelers' Intentions to Revisit, Journal of Travel Research, Vol. 41(1), pp. 38-45.

ReITSAMER B. F., BRUNNER-SPERdin A., 2017, Tourist Destination Perception and Well-being: What makes a Destination attractive? Journal of Vacation Marketing, Vol. 23(1) 55-72.

ROBINETTE S., BRAND C., LENZ V., 2000, Emotion Marketing: The Hallmark Way of Winning Customers for Life, New York: McGraw-Hill.

SAnChez J., Callarisa L. L. J., Rodri’Guez R. M., Moliner M.A., 2006, Perceived Value of the Purchase of a Tourism Product, Tourism Management, Vol. 27(4).

SANTINI F.O., LADEIRA W.J., SAMPIO C.H., 2018, Tourists' Perceived Value and Destination Revisit Intentions: The Moderating Effect of Domain-Specific Innovativeness, International Journal of Tourism research. Vol. 20(3).

Shanka T., Phau I., 2008, Tourism Destination Attributes: What the Non-visitors Say-Higher Education Students' Perceptions, Asia Pacific Journal of Tourism Research. Vol. 13(1), pp. 81-94.

Sheth J. N., Newman B. I., Gross B. L., 1991, Consumption Values and Market Choices, Cincinnati, OH: South-Western Publishing Co. Ltd.

StRAhILEVITZ M., Myers G. J., 1998, Donations to Charity as Purchase Incentives: How Well They Work May Depend on What You Are Trying to Sell, Journal of Consumer Research, Vol. 24(4), pp. 434-46.

SoutAR G., SWEeney J. C., 2001, Consumer Perceived Value: The Development of a Multiple Item Scale, Journal of Retailing, Vol. 77(2), 203-220.

SWEeney J., SOUTAR G. N., JOHNSON L. W., 1999, The Role of Perceived Risk in the Quality-Value Relationship: A Study in a Retail Environment, Journal of Retailing, Vol. 75(1), pp. 77-105.

SWeEney J., Soutar G., Whiteley A., Johnson L. W., 1996, Generating Consumption Value Items: a Parallel Interviewing Process Approach, Asia Pacific Advances in Consumer Research Russel Belk and Ronald Groves, Provo, UT : Association for Consumer Research (2), pp. 108-115.

SWeEney Jillian C., Geoffrey N. S., 2001, Consumer Perceived Value: The Development of a Multiple Item Scale, Journal of Retailing, Vol. 77(2), pp. 203-220.

UM S. K., CHON Y.H. Ro., 2006, Antecedents of Revisit Intention, Annals of Tourism Research, Vol. 33(4), pp. 41-58.

WeAVER D., LAWTON L., 2002, Tourism Management 2nd edition, Australia: John Wiley and Sons.

Williams P., SOUTAR G. N., 2000, Dimensions of Customer Value and the Tourism Experience: An Exploratory Study, Paper Presented at the Proceedings of the ANZMAC 2000 Visionary Marketing for the 21st Century: Facing the Challenge.

WoOdside A., KING R., 2001, An Updated Model of Travel and Tourism Purchase-Consumption Systems, Journal of Travel \& Tourism Marketing, Vol. 10(1), pp. 3-27.

Zeithaml V. A., 1998, Consumer Perceptions of Price, Quality, and Value: A Means-end Model and Synthesis of Evidence, Journal of Marketing, Vol. 52(3), pp. 2-22.

ZeITHAML V. A., BITNER M.O., GREMLER D.E., 2009, Services Marketing: Integrating Customer Focus Across the Firm, Mcgraw-Hill/Irwin. New York. 